\title{
ENHANCING PHYTOREMEDIATION OF Pb BY TREATING SOIL WITH CITRIC ACID AND GROWING WHITE JUTE (Corchorus capsularis, L.), AND RIVER RED GUM (Eucalyptus camaldulensis)
}

\author{
Magdy M. Niazy ${ }^{*}$ and M.E.M. Wahdan \\ Soils, Water and Environ. Res. Inst., Agric. Res. Cent. (ARC), Egypt
}

Received: 10/04/2017 ; Accepted: 06/06/2017

\begin{abstract}
Removal of toxic Pb metals from soil (phytoremediation) was evaluated using white jute (Corchorus capsularis, L.) and river red gum, (Eucalyptus camaldulensis) in presence of citric acid (CA). Lead was added to soil at $0,400,800$ and $1200 \mathrm{mg} \mathrm{Pb} \mathrm{kg}^{-1}$ soil as lead nitrate. Plant growth (120-day growth) of jute decreased with addition of $\mathrm{Pb}$ by 20 to $46 \%$ in white jute with no CA and 11 to $33 \%$ with CA; 18 to $40 \%$ for red gum with no CA and 10 to $26 \%$ with CA. Pb uptake increased with increased addition of $\mathrm{Pb}$. River red gum was more efficient as a phyto-remediator than jute. Citric acid enhanced the efficiency of both plants to extract $\mathrm{Pb}$ from soil.
\end{abstract}

Key words: Accumulation, Citric acid, lead, Corchorus capsularis, Eucalyptus camaldulensis, Phytoextraction.

\section{INTRODUCTION}

Lead occurs naturally only in small amounts within the earth's crust. Frequent use in many industrial processes such as mining and smelting activities, paints, mineral oils, explosives sewage sludge are all among sources contributing to environmental pollution with $\mathrm{Pb}$, (Chaney and Ryan, 1994 ; Henry, 2000 ; Abdel-Salam et al., 2015). Low bioavailability and extremely long duration of $\mathrm{Pb}$ retention by soil render such contamination being highly serious (Shaw, 1990). With soils and natural waters harbouring various forms of $\mathrm{Pb}$, the element would eventually enter the food chain via plants and animals and represent a serious permanent risk to human health. Average contents of $\mathrm{Pb}$ in the earth surface range between 10 and $20 \mathrm{mg} \mathrm{kg}^{-1}$, a level which may be rather safe, but when it rises to about $100 \mathrm{mgkg}^{-1}$ or more it becomes highly serious and indicates severe contamination (Fergusson, 1990). The majority of Pb contents in the environments is immobile, and soils nearby the highways contain considerable concentration of $\mathrm{Pb}$ which may be as high as
$180 \mathrm{mgkg}^{-1}$ due to emission of car exhaust fumes (Han et al., 2008). Cleanup technologies such as land filling and chemical treatment have been conducted in order to remediate $\mathrm{Pb}$ contaminated soils, but they are costly and may have adverse effects on soil properties (Pulford and Watson, 2003; Abdel-Salam et al., 2015). Tecnologies exploiting plants such as phytoremediation, phyto-extraction, phyto-filtration, phyto-stabilization, phyto-volatization and phyto-degradation may be used for such purposes (Garbisu and Alkorta, 2001). The phytoremediation method depends of using special plants which possess a high capacity for uptake of particular heavy metals (hyper accumulator plants) to be planted in the contaminated soil in order to remove as much possible of the heavy metal (Jing et al., 2007; Shakoor et al., 2013; Abdel-Salam et al., 2015). The plants are ultimately removed and translocated to a far cite and a destroyed, invariable by burning and buried in a very deep location and thus removed from the contaminated soil (Nascimento and Xing, 2006). Another method may be used in combination of

\footnotetext{
*Corresponding author: Tel. : +201093458689

E-mail address: amagdy16@gmail.com
} 
phytoremediation, is the use of particular chemicals (synthetic or organic) to enhance plant growth the metal uptake (Evangelou et al., 2007; Murakami et al., 2007; Abdel-Salam et al., 2015). This is called chemo-remediation, using chelating chemicals such as citric acid (CA), diethylene-triamine-pentaacetic acid (DTPA) and ethylene-diamine-tetraacetic acid (EDTA) (Sinhal et al., 2010; Szczygłowska et al., 2011; Bareen, 2012; Yeh et al., 2012; Chigbo and Batty, 2013). Chelating chemicals help plants to remove more metals (Anwer et al., 2012; Bareen, 2012). As an organic acid, CA has a high biodegradability and less leaching hazard as compared with synthetic chelating agents (Melo et al., 2008; Wuana et al., 2010; Bareen, 2012). Beside increasing metal solubility and uptake by plants, CA could increase the uptake of other nutrients by plants (Turgut et al., 2004; Yeh et al., 2012; Freitas et al., 2013). It proved effective in mobilization and phytoextraction of Cd (Sinhal et al., 2010).

Examples of hyper accumulator plants are Jute (Corchorus capsularis) and river red gum (Eucalyptus camaldulensis). Jute is a fiber crop, second in the world after cotton in terms of global production, and consumption (Ranjit et al., 2013). It is an annual fiber crop with tall stem and deep penetrating taproot. The plant grows fast and easily in nutrient-poor soil and makes a heavy quantity of valuable biomass. It produces soft, shiny and long fiber for wide usages. It is a completely biodegradable, recyclable and eco-friendly lingo-cellulose fiber. Red river gum is a big with a massive shoot system which should be able to accumulate (Nenman et al., 2012).

The objectives of the current study is to investigate the remediation ability of both plants in remediating soil contaminated with $\mathrm{Pb}$ under conditions of adding CA or in its absence.

\section{MATERIALS AND METHODS}

During summer season of 2015, the experiment was carried out in a greenhouse illuminated with natural light. In Kafr El-Hamam Agric. Res. Station, El Sharkia Governorate, Egypt. This site is located at $30^{\circ}-35 \mathrm{~N}$ latitude and $30^{\circ}-57 \mathrm{E}$ longitudes with an elevation of about 7 meters above mean sea level. Two plants i.e. white jute (Corchorus capsularis, L.) and river red gum (Eucalyptus camaldulensis) were used in a pot experiment, to measure their capacity to accumulate lead (6.5 kg soil per pot) from a clay soil contaminated with lead.The experimental design was a randomozed complete block, with three replicates. There were 12 treatments, 6 receiving lead at $0,400,800$ and $1200 \mathrm{mg} \mathrm{Pb}$ $\mathrm{kg}^{-1}$ soil (as lead nitrate $\mathrm{Pb}\left(\mathrm{NO}_{3}\right)^{2}$ ), and 6 receiving lead + citric acid at $0.98 \mathrm{~g} \mathrm{~kg}^{-1}$ soil. Each of the two plants received such treatments. Each pot was seeded with the relevant plant, then after germination, the seedlings were thinned to three plants per pot and grown for 120 days. Pots were watered so as soil moisture was kept at about $70 \%$ of water holding capacity. At end of experiment, plants were weighed and samples of soil and plants were taken for analysis. Method of analyses used for soil, plant and water were according to Page et al. (1982), Klute (1986) and to Stewart (1989).

Tables 1 and 2 show main properties of soil and water used in the experiment. Extractable lead was extracted from the soil using a mixture of 0.005 M DTPA (diethethylene triamine penta acetic acid) + 0.1 M TEA (triethanolamine) + $0.01 \mathrm{M} \mathrm{CaCl}_{2}$ at $\mathrm{pH} 7.3$ according to Lindsay and Norvell (1978).

\section{RESULTS AND DISCUSSION}

\section{Plant growth}

Results in Table 3 show effects of lead addition with or without citric acid on plant dry weight. Lead caused decreases in the different parts of dry weight plant ${ }^{-1}$. The decreases were greater where $\mathrm{Pb}$ was in greater contents. Also it was much lower where citric acid was present. It ranged from about 20 to $46 \%$ in white jute where no citric acid as compared with 11 to $33 \%$ where citric acid was present. Comparable values for red gum were 18 to $40 \%$ in absence of citric acid and 10 to $26 \%$ in its presence. Phytotoxic effects of heavy metals including lead induce several physiological and structural disorders in plants (Sharma and Dubey, 2005). Presence of citric acid was of positive effect in increasing the yield of plants. The alleviation effect of citric acid on the toxicity of lead to plant 
Zagazig J. Agric. Res., Vol. 44 No. (4) 2017

Table 1. Mechanical and chemical characteristics of the investigated soil before planting

\begin{tabular}{lccccccc}
\hline $\mathbf{P H}$ & $\mathbf{E C}$ & $\mathbf{C a C O}_{3}$ & $\mathbf{O M}$ & & \multicolumn{3}{c}{ Particle size distribution (\%) } \\
\cline { 5 - 8 } $\mathbf{1}: \mathbf{2 . 5}$ & dS.m $^{-\mathbf{1}}$ & $\mathbf{( \% )}$ & $\mathbf{( \% )}$ & Sand & Silt & Clay & Texture grade \\
\hline 7.99 & 2.3 & 3.70 & 2.30 & 23.64 & 30.11 & 46.25 & Clay \\
\hline
\end{tabular}

Table 2. Chemical analysis of water used for irrigation (Tap water)

\begin{tabular}{lcc}
\hline PH & EC dS.m & \\
\hline $\mathbf{7 . 3 8}$ & 0.52 & Pb $^{-1}$..$^{-1}$ \\
\hline
\end{tabular}

Table 3. Effect of $P b$ added to soil with or without citric acid in irrigation water on plant dry weight (shoots + roots) of 120-day old white jute (Corchorus capsularis), and river red gum (Eucalyptus camaldulensis)

\begin{tabular}{|c|c|c|c|c|c|c|c|c|}
\hline \multirow{3}{*}{$\begin{array}{c}\text { Added } \\
\text { Pb } \\
\left(\mathrm{mg} \mathrm{kg}^{-1}\right)\end{array}$} & \multicolumn{4}{|c|}{ White jute } & \multicolumn{4}{|c|}{ Red gum } \\
\hline & \multicolumn{2}{|c|}{ Without citric acid } & \multicolumn{2}{|c|}{ With citric acid } & \multicolumn{2}{|c|}{ Without citric acid } & \multicolumn{2}{|c|}{ With citric acid } \\
\hline & g plant $^{-1}$ & $\begin{array}{c}\text { Decrease } \\
(\%)\end{array}$ & g plant $^{-1}$ & $\begin{array}{c}\text { Decrease } \\
(\%)\end{array}$ & g plant $^{-1}$ & $\begin{array}{c}\text { Decrease } \\
(\%)\end{array}$ & g plant $^{-1}$ & $\begin{array}{c}\text { Decrease } \\
(\%)\end{array}$ \\
\hline $\mathbf{0}$ & 8.95 & - & 9.15 & - & 13.65 & - & 14.53 & - \\
\hline 400 & 7.15 & 20.1 & 8.19 & 10.5 & 11.23 & 17.7 & 13.15 & 9.5 \\
\hline 800 & 5.17 & 42.2 & 7.89 & 13.8 & 9.15 & 33.0 & 12.57 & 13.5 \\
\hline 1200 & 4.75 & 46.9 & 6.18 & 32.5 & 8.17 & 40.1 & 10.79 & 25.7 \\
\hline LSD 0.05 & 1.51 & 2.7 & 1.63 & 5.0 & 1.74 & 3.8 & 1.64 & 5.6 \\
\hline
\end{tabular}

is shown in the low negative toxic effect on plant. Citric acid exhibits a chelation to soluble lead (Sinhal et al., 2010; Szczygłowska et al., 2011; Ehsan et al., 2014), thus reducing its retarding effect of plant growth.

\section{Uptake of Pb by Plant}

Results in Table 4 show the uptake values of lead by plants (roots + shoot). Addition of lead increased $\mathrm{Pb}$ uptake. The increases were greater with the increase in $\mathrm{Pb}$ addition. Also the uptake was much greater in presence of CA. The increase in uptake ranged from about 10 folds to
16 folds in the white jute plant where no citric acid as compared with.. 13 folds to 20 folds in presence of CA. Comparable values for red gum were 15 folds 19 folds in absence of CA and 19 folds to 31 folds in its presence. Increased uptake of $\mathrm{Pb}$ with increasing addition of $\mathrm{Pb}$ is a direct consequence of added $\mathrm{Pb}$. The increases caused by citric acid indicates the chelation effect of the acid on the added $\mathrm{Pb}$ as well as its enhancement effect on plant growth. Citric acid addition was reported to increase the uptake of heavy metal due to its chelating effect (Hocking et al., 1997). 
Table 4. Effect of $\mathrm{Pb}$ added to soil with or without citric acid in irrigation water on $\mathrm{Pb}$ uptake (in roots + shoots) of 120-day old white jute (Corchorus capsularis), and river red gum (Eucalyptus camaldulensis)

\begin{tabular}{|c|c|c|c|c|}
\hline \multirow{2}{*}{$\begin{array}{c}\text { Added Pb } \\
\left(\mathrm{mg} \mathrm{kg}^{1}\right)\end{array}$} & \multicolumn{2}{|c|}{ White Jute } & \multicolumn{2}{|c|}{ River red gum } \\
\hline & Without citric & With citric & Without citric & With citric \\
\hline 0 & 192 & 294 & 358 & 521 \\
\hline 400 & 2113 & 4175 & 5581 & 10167 \\
\hline 800 & 2750 & 5512 & 6211 & 12435 \\
\hline 1200 & 3433 & 6296 & 7070 & 16507 \\
\hline LSD 0.05 & 24 & 29 & 31 & 32 \\
\hline
\end{tabular}

\section{Lead in Soil at End of Plant Growth}

Data in Table 5 show the lead contents in soil at end of plant growth. Contents of total $\mathrm{Pb}$ were about $19 \mathrm{mg} \mathrm{kg}^{-1}$ in soil of the white jute, and 15 $\mathrm{mg} \mathrm{kg}^{-1}$ in soil of the river red gum increased up to 35 folds by increased addition of Pb.The DTPA-extractable contents amounted to a very small fraction of the total (from $2 \%$ to $5 \%$ of total $\mathrm{Pb}$ ).Contents in soils treated with CA were lower, demonstrating the chelation effect of CA.

\section{Bio-concentration Factor (BCF)}

The bio-concentration factor (BCF) is the ratio of metal content in the plant roots to that in soil (Malik et al., 2010). Values of BCF for lead in soil under jute varied by 0.92 to 2.93 (Fig. 1). The lowest was by the treatment receiving the low rate $\mathrm{Pb}$ with added $\mathrm{CA}$ and the highest was given by the treatment receiving the low rate $\mathrm{Pb}$ with highest addition of $\mathrm{Pb}$. Values for the soil under the red gum plant ranged from 0.51 to 7.92 with a pattern of change rather similar to that of the soil under the jute plant. Arifin et al. (2012) noted that BCF for the heavy metal of Cd decreased with increase of the metal in soil indicating a restriction in soil-root transfer where there is a high rate of the metal in the soil. Fitz and Wenzel (2002) concluded that plants of BCF values less than one not suitable as phytoremediators of heavy metals. According to Yoon et al. (2016), plants which are suitable as phytoremediators include wiregrass gentian (Gentiana pennelliana) which is capable of accumulating heavy metal in the roots.

\section{Overall Assessment and General Conclusions}

Lead showed an extreme phytotoxicity to plants, most probably through its severe physiological disorders in plants (Sharma and Dubey, 2005). Reduction in protein synthesis (Stiborova et al., 1987) and photo-synthesis, and damage to cell and sub-cellular organelles (Hauck et al., 2003) are among the negative effect caused by the metal. The decrease in plant growth exhibited in the current study reflects the retarding effects in plant physiology and metabolism (Alia and Saradhi, 1991; Baker and Walker, 1990). The toxicity increased with increases in the metal in the root zone (Gao et al., 2010). Presence of citric acid alleviated the toxic effect of the metal. The acid must have caused positive metabolic processes in plants including mobilization of weakly soluble essential nutrients (Strom et al., 2001). Gao et al. (2010) observed that citric acid increased plant growth of black nightshade berries (Solanum nigrum). Najeeb et al. (2011) noted a promoting effect of citric acid to the growth for common rush (or soft rush) herbaceous flowering plant (Juncus effuses) under high contents of $\mathrm{Mn}$ in the root zone Ehsan et al. (2014) noted alleviating effect of citric acid to Rapeseed (Brassica napus), under $\mathrm{Cd}$ high contents in the root zone. High contents of $\mathrm{Pb}$ around plant roots causes disruption to plant chloroplasts, protein synthesis, and photosynthesis (Ali et al., 2013b, 2013a and Vassilev et al., 1995). Disruption of chloroplasts was attributed to a rise in the activity of the chlorophyllase enzyme (Hegedus et al., 2001). 
Table 5. Effect of $\mathbf{P b}$ added to soil with or without citric acid in irrigation water on total and DTPA-extractable $\mathrm{Pb}\left(\mathrm{mg} \mathrm{kg}^{-1}\right)$ remaining in soil after growth of 120-day old white jute (Corchorus capsularis), and river red gum (Eucalyptus camaldulensis)

\begin{tabular}{|c|c|c|c|c|c|c|c|c|}
\hline \multirow{3}{*}{$\begin{array}{l}\text { Treatment } \\
\text { Pb mg kg }\end{array}$} & \multicolumn{4}{|c|}{ White jute } & \multicolumn{4}{|c|}{ River red gum } \\
\hline & \multicolumn{2}{|c|}{ Without citric acid } & \multicolumn{2}{|c|}{ With citric acid } & \multicolumn{2}{|c|}{ Without citric acid } & \multicolumn{2}{|c|}{ With citric acid } \\
\hline & Total & $\begin{array}{c}\text { DTPA } \\
\text { Extractable }\end{array}$ & Total & $\begin{array}{c}\text { DTPA } \\
\text { Extractable }\end{array}$ & Total & $\begin{array}{c}\text { DTPA } \\
\text { Extractable }\end{array}$ & Total & $\begin{array}{c}\text { DTPA } \\
\text { Extractable }\end{array}$ \\
\hline $\mathbf{0}$ & 18.7 & 0.9 & 12.1 & 0.55 & 15.5 & 0.3 & 9.1 & 0.3 \\
\hline 400 & 319.8 & 6.8 & 173.8 & 10.1 & 210.0 & 4.4 & 93.9 & 5.8 \\
\hline 800 & 464.5 & 31.8 & 270.4 & 40.3 & 370.7 & 25.7 & 197.6 & 33.8 \\
\hline 1200 & 664.7 & 55.7 & 458.0 & 70.2 & 549.0 & 39.8 & 230.3 & 42.9 \\
\hline LSD 0.05 & 17.2 & 4.8 & 16.1 & 5.4 & 14. & 3.2 & 12.6 & 3.9 \\
\hline
\end{tabular}

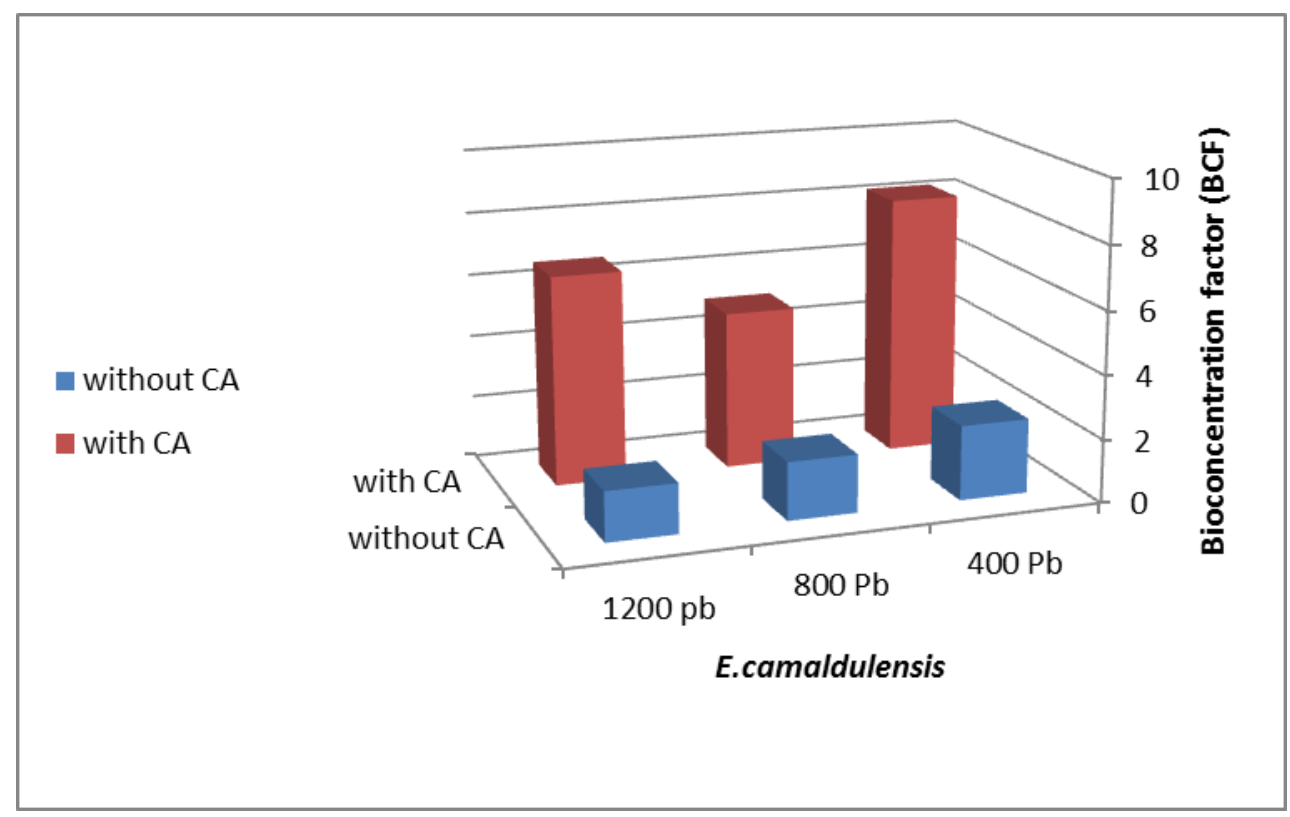

Fig. 1. Bioconcentration factor as influenced by different lead concentrations including (lead addition, 400, 800 and $1200 \mathrm{mg}$ lead $\mathrm{kg}^{-1}$ ) with or without citric acid in Corchorus capsularis, L. and Eucalyptus camaldulensis

Disruption of gas exchange and plant stomatal conductance, which would lead to reduce the rate of chlorophyll synthesis, may occur under stress of high heavy metal contents (Balakhnina et al., 2005).

The alleviating effect of citric acid may be due to increases in chlorophyll contents and gas exchange rate (Wang et al., 2004). The increased uptake of elements from soils caused by citric acid was reported by Lambers et al. (2006). Citric acid and other low molecular organic acids produce protons and electrons which remove metals in the rhizosphere (Jones and Brassington, 1998). Williams et al. (2006) concluded that citric acid increased the uptake of Cd in Indian mustard (Brassica juncea) plants. Processes causing metal accumulation in plant include mobilization and uptake compartmentation, sequestration within plant roots, increased efficiency of xylem loading and storage in leaf cells. (Kabata-Pendias and Pendias, 1989, Marschner, 1995, Willams, 2000 and Clemens, 2001). 
The capacity of phyto-remediator plants in acquiring heavy metals is a function of the contents of metal in soil, soil physical and chemical properties, physiological state of the plants, specificity of the metal and the mechanism of acquisition (Raskin et al., 1994). Plants respond to heavy metal toxicity in different ways including immobilization, exclusion, compartmentalization and synthesis of metallothioneins (cysteine-rich proteins which binds heavy metals) (Sanita di Toppi and Gabbrtielli, 1999)

The current study shows that red river gum (Eucalyptus camaldulensis) is more efficient as a phytoremediation plant than jute (Corchorus capsularis), and that citric acid can enhance such remediation.

\section{REFERENCES}

Abdel-Salam, A.A., H.M. Salem, M.A. AbdelSalam and F. Seleiman (2015). In Sheramets, I and Verma, A. (eds) Heavy metal contamination of soils, Soil biology series. Springer Int. Pub., Switzerland, 44 : 299-309.

Ali, B., B. Wang, S. Ali, M.A. Ghani, M.T. Hayat, C. Yang, L. Xu and W.J. Zhou (2013a). 5-amino levulinic acid ameliorates the growth, photosynthetic gas exchange capacity and ultrastructural changes under cadmium stress in Brassica napus L. J. Plant Growth Regul., 32: 604-614.

Ali, B., Q.J. Tao, Y.F. Zhou, R.A. Gill, S. Ali, M.T. Rafiq, L. Xu and W.J. Zhou (2013b). 5amino levolinic acid mitigates the cadmiuminduced changes in Brassica napus as revealed by the biochemical and ultrastructural evaluation of roots. Ecotoxicol. Environ. Saf., 92:271-280.

Alia, P.P. and P. Saradhi (1991). Proline accumulation under heavy metal stress. J. Pl. Physiol., 138: 554-558

Anwer, S., M.Y. Ashraf, M. Hussain, M. Ashraf, and A. Jamil (2012). Citric acid mediated phytoextraction of cadmium by maize (Zea mays L.) Pak. J. Bot., 44 (6): 1831-1836.

Arifin, A., A. Parisa, A.H. Hazandy, T.M. Mahmud, N. Junejo, A. Fatemeh, S. Mohsen, M.E. Wasli and N.M. Majid (2012).
Evaluation of cadmium bioaccumulation and translocation by Hopea odorata grown in a contaminated soil, 11: 7472-7482.

Baker, A.J.M. and P.L. Walker (1990). Eco physiology of metal uptake by tolerant plants. In: Shaw, AJ (ed.), Heavy metal tolerance in plants: Evolutionary Aspects, CRC Press, Boca Raton, FL, USA, 55-177

Balakhnina, T., A. Kosobryukhov, A. Ivanov, and V. Kreslavskii (2005). The effect of cadmium on $\mathrm{CO}_{2}$ exchange, variable fluorescence of chlorophyll, and the level of antioxidant enzymes in pea leaves. Russ. J. Plant Physiol., 52:15-20.

Bareen, F.E. (2012). Chelate assisted phytoextraction using oilseed brassicas. Environ. Pollut., 21: 289-311.

Chaney, R.L. and J.A. Ryan (1994). Risk based standards for arsenic, lead and cadmium in urban soils. Frankfurt: EDCHEMA, Germany.

Chigbo, C. and L. Batty (2013). Effect of EDTA and citric acid on phyto-remediation of $\mathrm{Cr}$ B]a] P-co-contaminated soil. Environ. Sci. Pollut. Res., 1-9

Clemens, S. (2001). Molecular mechanisms of plant metal homeostasis and tolerance. Planta. 212 :45 - 486.

Ehsan, S., S. Ali, S. Noureen, K. Mehmood, M. Farid, W. Ishaque, M.B. Shakoor and M. Rizwan (2014). Citric acid assisted phytoremediation of Cd by L. Ecotoxicol. Environ. Rape seed (Brassica napus), 106: 164-172.

Evangelou, M.W.H., M. Ebel and A. Schaeffer (2007). Chelate assisted phytoextraction of Heavy metals from soil. Effect, mechanism, toxicity, and fate of chelating agents. Chem., 68: 989-1003.

Fergusson, J.E. (1990). The Heavy Elements Chemistry Environmental Impact and Health Effects. Pergamon Press, Oxford, UK.

Fitz, W.J. and W.W. Wenzel (2002). Arsenic transformation in the soil-rhizosphere plant system: fundamentals and potential application of phytoremediation. J. Biot., 99: 259-78. 
Freitas, E.V., C.W. Nascimento, A. Souza and F.B. Silva (2013). Citric acid-assisted phytoextraction of lead: a field experiment. Chem., 92: 213-217.

Gao, Y., C.Y. Miao, L. Mao, P. Zhou, Z.G. Jin and W.J. Shi (2010). Improvement of phytoextraction and ant oxidative defense of SolanumnigrumL.under cadmium stress by application of cadmium-resistant strain and citric acid synergy. J. Hazard. Mater, 181: 771-777.

Garbisu, C. and I. Alkorta (2001). Phytoextraction: A costeffective plant-based technology for the removal of metals from the environment. Bioresour Technol., 77(3): 229-236.

Han, Y.L., S.Z. Huang, J.G. Gu, S. Qiu and J.M. Chen (2008). Tolerance and accumulation of lead by species of Iris L. Ecotoxicol., 17 (8): 853-859.

Hauck, M., A. Paul, S. Gross and M. Raubuch (2003). Manganese toxicity in epiphytic lichens: chlorophyll degradation and interaction with iron and phosphorus. Environ. Exp. Bot., 49:181-191.

Hegedus, A., S. Erdel and G. Horvath (2001). Comparative studies of $\mathrm{H}_{2} \mathrm{O}_{2}$ detoxifying enzymes in green and greening barely seedlings under Cd Stress. Pl. Sci., 160 : 1085-1093.

Henry, J.R. (2000). An overview of the phytoremediation of lead and mercury. Washington, DC: United States Environ. Prot. Agency.

Hocking, P.J., G. Keerthisinghe, F.W. Smith, and P.J. Randall (1997). Comparison of the ability of different crop species to assess poorly-available soil phosphorus.In: An do, TokyoT.(Ed.),Plant Nutrition for Sustainable Food Production and Environment. Kluwer Acad. Publish., 305-308.

Jing, Y.D., Z.L. He and X.E. Yang (2007). Role of soil rhizobacteriain phytoremediation of heavy metal contaminated soils. J. Zhejiang Univ. Sci., 8 : 192-207.

Jones, D.L. and D.S. Brassington (1998). Sorption of organic acids in acid soils and its implications in the rhizosphere. Euras. J. Soil Sci., 49:112-119.
Kabata-Pendias, A. and H. Pendias (1989). Trace Elements in the Soil and Plants. CRC Press, Boca Raton, Florida., USA.

Klute, A. (1986) Methods of Soil Analysis, Part1: Physical and mineralogical analysis, $2^{\text {nd }} E d$. Ame. Soc. Agron. Inc. Madison, WI, USA.

Lambers, H., M.W. Shane, M.D. Cramer, S.J. Pearse and E.J. Veneklaas (2006). Root structure and functioning for efficient acquisition of phosphorus: Matching morphological and physiological traits. Ann. Bot., 98 (4): 693-713.

Lindsay, W.L. and W.A. Norvell (1978). Development of DTPA soil test for Zinc, iron, manganese and copper. Soil Soc. Ame. J., 42: 421 - 428.

Malik, S., K. Kakuda, Y. Sasaki, T. Ando, H. Fujii and H. Ando (2010). Relationship between mineral composition or soil texture and available silicon in alluvial paddy soils on the Shounai Plain, Japan. Soil Sci. Pl. Nut., 55: 300-308

Marschner, H. (1995). Mineral Nutrition of Higher Plants. Acad. Press, NY,USA.

Melo, E.E.C., C.W.A. Nascimento, A.M.A. Accioly and A.C.Q. Santos (2008). Phytoextraction and fractionation of heavy metals in soil after multiple applications of natural chelants. Agric. Sci., 65:61-68.

Murakami, M., N. Ae and S. Ishikawa (2007). Phyto-extraction of cadmium by rice (Oryza sativa L.), soybean (Glycine max (L.) Merr.), and maize (Zea mays L.). Environ. Pollut., 145: 96-103.

Najeeb, U., G. Jilani, S. Ali, M. Sarwar, L. Xu, and W.J. Zhou (2011). Insight into cadmium induced physiological and ultra-structural disorders in Juncus effusus L. and its remediation through exogenous citric acid. J. Hazard. Mater., 186:565-574.

Nascimento, C.W.A. and B. Xing (2006). Phytoextraction: A review on enhanced metal availability and plant accumulation. Sci. Agricola, 63:299-311.

Nenman, D.V., N.D. Nimyel and E.D. Ishaya (2012). The Potentials of Eucalyptus 
camaldulensis for the Phytoextraction of Six Heavy Metals in Tin - mined Soils of Barkin Ladi L.G.A. of Plateau State Nigeria. Int. J. Eng. Res. and Appl., 2 : 346-349.

Page, A.L., R.H. Miller and D.R. Keeny (1982). Methods of Soil Analysis, Part 2: Chemical and Biological Properties. $2^{\text {nd }}$ Ed. Am. Soc. Agron.Inc. Madison, WI, USA.

Pulford, I.D. and C. Watson (2003). Phytoremediation of heavy metalcontaminated land by trees- a review. Environ. Int., 29 (4):529-540.

Ranjit, K.G., S. Tanee, N. Sutkhet and P. Chalermpol (2013). Phenotypic variation and the relationships among jute (Corchorus species) genotypes using morpho-agronomic traits and multivariate analysis. Aust. J. Crop Sci., 7: 830-842.

Raskin, I., P.N. Kumar, S.D. Ushenkov and D. E. Salt (1994). Bio concentration of heavy metals by plants (Review article). Current Opinion in Biotechnol., 5: 285- 290.

Sanita di Toppi, L. and R. Gabbrielli (1999). Response to cadmium in higher plants. Environ. and Exp. Bot., 41:105-130.

Shakoor, M.B., S. Ali, M. Farid, M.A. Farooq, H.M. Tauqeer, U. Iftikhar, F. Hannan and S.A. Bharwana (2013). Heavy metal pollution, a global problem and its remediation by chemically enhanced phytoremediation: A review. J. Biol. Environ. Sci., 3 (3):2-20.

Sharma, P. and R.S. Dubey (2005). Pb toxicity in plants .Braz. J. Pl. Physiol.,17:35-52.

Shaw, A.J. (1990). Heavy metal tolerance in plants: evolutionary aspects. CRC, Boca Raton, USA.

Sinhal V.K., A. Srivastava and V.P. Singh (2010). EDTA and citric acid mediated phyto-extraction of $\mathrm{Zn}, \mathrm{Cu}, \mathrm{Pb}$ and $\mathrm{Cd}$ through marigold (Tagetes erecta). J. Environ. Biol., 31:255-259.

Stewart, E.A. (1989) Chemical Analysis of Ecological Materials, $2^{\text {nd }}$ Ed., Blackwell Scientific, Oxford, UK.
Stiborova, M., M. Ditrichova and A. Brezinova (1987). Effect of heavy metal ions on growth and biochemical characteristics of photosynthesis of barley and maize seedlings. Biol. Pl., 29 : 453-467.

Strom, L., A.G. Owen, D.A. Godbold and D.L. Jones (2001). Organic acid behavior in a calcareous soil: sorption reactions and biodegradation rates. Soil Biol. Biochem., 33: 2125-2133.

Szczygłowska, M., A. Piekarska, P. Konieczka and J. Namiesnik (2011). Use of brassica plants in the phytoremediation and biofumigation processes. Int. J. Mol. Sci., 12: $760-771$.

Turgut, C., M.K. Pepe and T.J. Cutright (2004). The effect of EDTA and citric acid on phytoremediation of $\mathrm{Cd}, \mathrm{Cr}$, and $\mathrm{Ni}$ from soil using Helianthus annuus. Environ. Pollut., 131:147-154.

Vassilev, A., I. Iordanov, E. Chakalova and V. Kerin (1995). Effect of cadmium stress on growth and photosynthesis of young barley (H. vulgare L.) plants. 2. Structural and functional changes in the photosynthetic apparatus. Bulg. J. Pl. Physiol., 21:12-21.

Wang, L.J., W.B. Jiang and B.J. Huang (2004). Promotion of 5-amino levulinic acid on photosynthesis of melon (Cucumismelo) seedlings under low light and chilling stress conditions. Physiol. Plantarium, 121 : 258-264.

Williams, C.A., D. Nascimento, D. Amarasiriwardena and B. Xing (2006). Comparison of natural organic acids and synthetic chelates at enhancing phytoextraction of metals from a multi-metal contaminated soil. Environ. Pollut., 140: 114- 123.

Williams, L.E. (2000): Emerging mechanisms for heavy metal transport in plants. Biochim. Biophys. Acta., 1465: 104-126.

Wuana, R.A., F.A. Okieimen and J.A. Imborvungu (2010). Removal of heavy metals from a contaminated soil using organic chelating acids. Int. J. Environ. Sci. Tech., 7 (3): 485-496.

Yeh, T.Y., C.F. Lin, C.C. Chuang and C.T. Pan (2012). The Effect of Varying Soil Organic Levels on Phytoextraction of $\mathrm{Cu}$ and $\mathrm{Zn}$ 
uptake, enhanced by chelator EDTA, DTPA, EDDS and Citric Acid, in Sunflower (Helianthus annuus), Chinese Cabbage (Brassica campestris), Cattail (Typha latifolia), and Reed (Phragmites communis). Environ. Anal. Toxicol., 2 - 5
Yoon, J., X. Cao, Q. Zhou and L.Q. Ma (2016). Accumulation of $\mathrm{Pb}, \mathrm{Cu}$, and $\mathrm{Zn}$ in native plants growing on a contaminated Florida site. Sci. Total Environ., 368:456464.

\section{حامض الستريك لتعزيز المعالجة النباتية للرصاص باستخدام الجوت الأبيض والكافور البلاي}

$$
\begin{aligned}
& \text { مجدي محمد نيازي- مصطفى عيسى وهدان }
\end{aligned}
$$

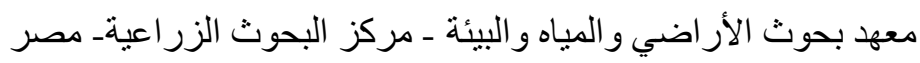

استخدام النباتات لإز الة المعادن الثقبلة والسامة من التربة (المعالجة النباتية) كبديل فعال و اقل تكلفة من الأساليب

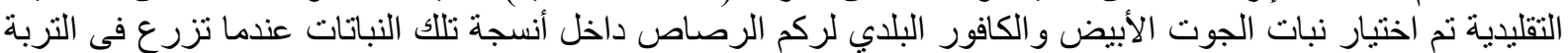

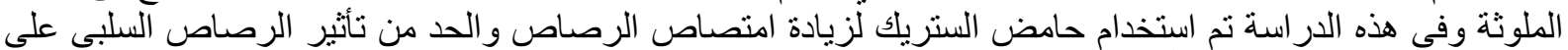

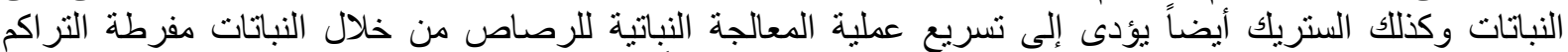

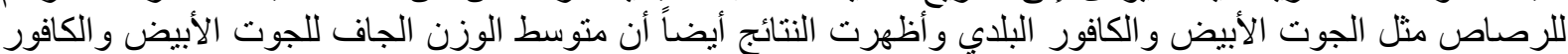

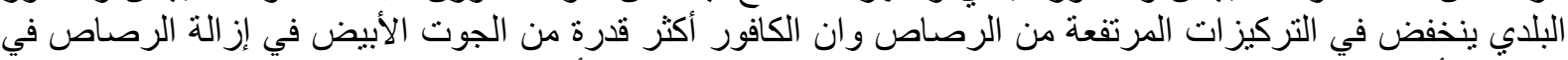

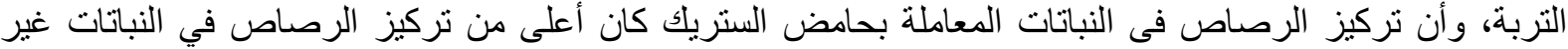

أستاذ الأر اضي - كلية الزر اعة بمشتهر - جامعة بنها. أستاذ الأر اضي المتفرغ غ ـ كلية الزر اعة - جامعة الزقازيق. 